\title{
SNURF Gene
}

National Cancer Institute

\section{Source}

National Cancer Institute. SNURF Gene. NCI Thesaurus. Code C104854.

This gene may be involved in cerebral development. 